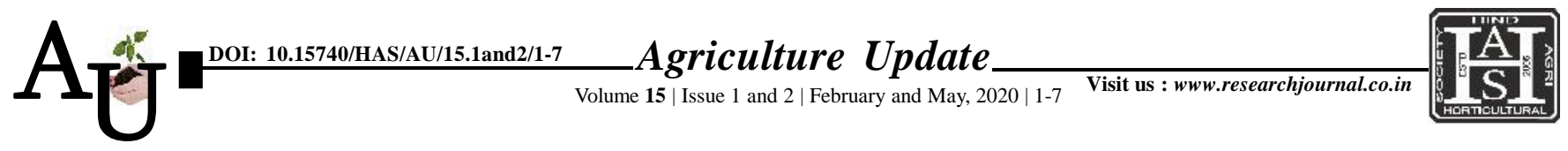

ISSN-0973-1520

\title{
Research автіcle: Utilization of information and communication technology tools by the extension personnel of Kerala
}

\author{
S. Helen, Smitha Baby and N. Mridula
}

Article Chronicle:

SUMMARY : This study was conducted to analyse the utilization pattern of information and Received :

23.12.2019;

Revised:

23.03.2020;

Accepted :

01.04.2020

KEY Words :

ICT tools, Extension personnel, Utilization Index communication technologies (ICTs) among the agricultural extension personnel of Kerala. Data were collected from 150 Agricultural Officers working in different districts of Kerala. It was observed that 66 per cent of the extension personnel were females, more than two-third of the extension personnel $(71.33 \%)$ had only medium level of innovation proneness. Almost three-fourth $(74.66 \%)$ of the extension personnel did not receive trainings related to ICTs. With regard to the attitude towards ICTs, majority $(86.66 \%)$ of the extension workers were under medium category. The ICT tools with low extent of accessibility were decision support system, video camera, video conferencing and kiosk, with less than 25 per cent. The respondents were evenly distributed among the categories of very less frequent users, less frequent users, frequent users with 26 per cent each and most frequent users with 22 per cent only. More than 70 per cent of the respondents spent 1-5 hrs per week in using various ICT tools.

How to cite this article : Helan, S., Baby, Smitha and Mridula, N. (2020). Utilization of information and communication technology tools by the extension personnel of Kerala. Agric. Update, 15(1 and 2): 1-7; DOI : 10.15740/HAS/AU/15.1and2/1-7. Copyright@ 2020: Hind Agri-Horticultural Society.

Author for correspondence :

S. Helen

Central Training

Institute, Kerala

Agricultural University,

Mannuthy, Thrissur

(Kerala) India

Email: helen.s@kau.in

See end of the article for

authors' affiliations 